\title{
'Transfers' in Hungarian Literature from Vojvodina
}

\author{
Erika BENCE \\ University of Novi Sad (Serbia), Faculty of Philosophy \\ Department of Hungarian Studies \\ erikazambo@eunet.rs
}

\begin{abstract}
The study examines the variants of the postmodern phenomena of literary 'transfer' ('trans-correspondence, 'transpass') and their relationships with Hungarian literature (in Vojvodina) from the beginnings (the creative tradition of Kornél Szenteleky's oeuvre) up to the events of present-time literary history (e.g., to the publication of Esti by Péter Esterházy). Referential aspects (the literary themes of the railway, the train, the change of trains), specific contexts (e.g., Kornél Esti as a contextual 'transferring' literary character) and metaphorical contents (e.g., the meanings of the straight line and the plane in the literature of the region) come into the focus of our research. Another significant aspect of the research is the interpretation of the intricate web of cross-cultural 'transfers' (between the works of Dezső Kosztolányi-Danilo Kiš-Péter Esterházy). The dominant motif of Central-Eastern European man's experience of space is the straight line of the flatlands: lacking the sea-experience of the Southern European or of the more southern regions, as well as the related mythical experience of the world, infinity-experience, or reality perceptions hosting unrealities. The trip in this sense is an intermediate form of life: movement towards other shapes. The direction and extent of this movement has always been defined by the 'straight line,' the main road, and later the straight line of the railway. ${ }^{1}$
\end{abstract}

Keywords: Kornél Esti, straight line, transfer, trans-correspondence, travel, train, Hungarian literature, Hungarian literary representation in Vojvodina, Danilo Kiš’s oeuvre

\section{Transfer, trans-correspondence, transpass}

The term literary 'transfer' was borrowed from the study entitled Esti Kornél „átszállásai” a vajdasági magyar irodalomban [Kornél Esti’s Transfers in Hungarian Literature in Vojvodina] by Éva Hózsa (2009, 109-117). It is to be interpreted as

1 The study was conducted within project no. 178017 of the Ministry of Science and Education of Serbia. 
a term denoting evolutionary connections of Hungarian literature in Vojvodina, 'transfers' of poetic phenomena from one literary work into another, and intertextual 'connections,' by which the intermediate movements of the given literature can be presented. It simultaneously shows concrete intertextual connections and metaphorical contents; it may describe one of the thematic planes and genre-creating variants of life form in regional Hungarian literature: a literary mesh woven from travel, (e)migration, leaving, roads/military ways/railways, (straight) lines and the lines created by sands; it is a border novel/history comprehensible as a travelogue/ novel. 'Transfer' as a key expression in this case does not only convey such tropic implications as 'crosstalk', 'cross-correspondence,' 'transpass,' but also the referential aspects ('transfer' to another train line, to catch the other 'connection').

The 'transferring' passenger of Hungarian literature is Kornél Esti: “...he would always 'travel on,' more precisely, 'travel further,' from time to time, just from one vehicle to the other, crossing from one text into another" (Hózsa 2011, 71-72). ${ }^{2} \mathrm{He}$ is the epitome of the duality of leaving-returning, departure-arrival, flatland (Sárszeg, Porváros)—seaside (Fiume), straight—curved (still—dynamic). While in his own time Kornél Esti plays the role of the traveller withdrawing from the boredom of the motionless flatlands (but inevitably returning to his homeland), in the 1990s he becomes the alter ego of a fleeing, transborder, nostalgic character of Hungarian literature in Vojvodina. Hózsa connects this attitude to the 'elementary situation of discontinuity' (ibid): it refers to changes of countries, living space cut up by borders, broken life forms in the region. The reflected 'transfers' of Kornél Esti are well known to us: the novels Esti Kornél utolsó hazalátogatása [Last Homecoming of Kornél Esti] by Károly Dudás (1996, 164-166), Után-utazás Esti Kornél fiumei gyorsán [Travelling on Kornél Esti's Track on the Fiume Express Train] by Erzsébet Juhász (1998, 59-65), and two short stories about Esti in Tükörcselek [Mirror Tricks], a collection of short stories by Árpád Nagy Abonyi (2003) and his novel Budapest, Retour (2008) function as emblematic examples of intertextual 'transfers' and 'connections.' In 2010, our "Kornél Esti” 'transferred' to Esti, Péter Esterházy's work, and travelled on.

The visualization of the silhouette-like or referential attitude (metaphorical connections) of the Traveller can also be exemplified by several literary contexts and textual discourses: viewing their situation, the nostalgia towards the AustroHungarian Monarchy and awareness of separation determined the lives of the travellers, i.e., the members of the Patarcsics family; the purpose of termination or 'alleviation' (Juhász 2001) of administrative/political borders on the one hand, and the psychological/mental separation, on the other, is served by travelling, 'riding on the tram' or 'taking the train,' as is done for a whole day by Angeline Nenadovicsriding on the tram around Novi Sad (Egy villamos végállomást jelzó csengetése [A Ring for the Final Tram Station]), or as the members of the Patarcsics family

2 Quotations from Hungarian and Serbian literature were translated by the author. 
do, actually and symbolically travelling "from Graz to Subotica, from Szeged to the Isonzo valley, from Timişoara to Bratislava, from Novi Sad to Arad, back and forth, all around" (Linzi Anziksz [Postcard from Linz]) (Juhász 2001, 94). However, the Central European literary 'transfers' loosely contain Ildikó Lovas's latest novel written subsequent to the recent Yugoslav wars, entitled Kijárat az Adriára [Access to the Adriatic] (2005), in which although they do drive "through Bosnia... down to the coast" (Lovas 2005, 286), wallowing in the "sand from Bácska," "among the props of provincial environment" (idem, 199) is seen in contrast with the 'access' to the seaside, a 'transfer' into another kind of space; as well as 'changing' to the Fiume train by Kornél Esti in Dezső Kosztolányi’s novel.

Literary discourses can be linked to the essay Dezsố Kosztolányi and Danilo Kiš by Sava Babić-cited frequently-which discusses the possibilities of translating Kornél Esti. He explains the translation of Kornél Esti's name into Kornel Večernji (Vespertine) as a necessity: "Although names are not to be translated, I have nevertheless translated Kornél Esti's name since the Serbian reader does not understand what Esti means; therefore, if it gets published, the name will be Kornel Večernji." (Babić 2007, 164) Seen from the viewpoint of Hungarian literature in Vojvodina, it conveys more than just translating into another language: at the same time, what takes place is the 'takeover' of one of its most important metaphors and connotations into Serbian literature.

Sticking to the railway terminology and metaphors from the end of the $20^{\text {th }}$ century regional literature (e.g., Árpád Nagy Abonyi), literary 'transfers' are generally of 'round trip' character. In one of her studies (2009a) Éva Hózsa discusses the 'infiltration' of Danilo Kišs's prose-poetics into the novels of Péter Esterházy. A similar phenomenon can be documented-studying the textual discourse of Dezső Kosztolányi’s A szegény kisgyermek panaszai [The Poor Little Boy’s Grievances] (1910) and Danilo Kiš’s short story-novel Korai bánat [Early Sorrows] (1971) (Milosevits 1998, 499)—in a 'comparative dictionary,' which has been done by Éva Hózsa (2009a, 112-117). Roland Orcsik $(2004,205)$ sees this as an archeological procedure and places the prose of Ottó Tolnai and Attila Balázs into the same discourse. Jutka Rudaš views several works by Danilo Kiš as pretexts to Esterházy’s novels: thus, she examines the discourse (Rudaš 2008, 149-161) in the context of Fövenyóra [Sand Glass] (1972) and Harmonia Cælestis (2000), Anatómiai lecke [Lessons in Anatomy] (1978) and Javított kiadás [Revised Edition] (2000).

\section{Straight line, railway, train}

As known, the 'straight line' of Hungarian literature in Vojvodina was drawn by Kornél Szenteleky. "Soberness draws straight lines..."-he wrote in 1928, in his poem Bácskai éjjel [Night in Bácska]. In 1929, his novel Isola Bella-which 
was published posthumously $(1944,1993)$ in Vojvodina-Kornél Esti’s preview is created in the character of Szabolcs, a decadent writer from Bácska, who flees from the "sluggish, passionless [...] land of joyless souls" (Szenteleky 1993, 187) to the world of Sicily's Beautiful Isle-as Kornél Esti does towards the 'vast' sea. Árpád Nagy Abonyi's Esti alter ego also returns home from his Western European travels to "the dusty town in Bácska" where "people already die many times during their lives" (Nagy Abonyi 2003, 91).

The dominant motif of Central Eastern European people's space experience is the straight line of the flatlands: lacking the sea-experience of the Southern European or even of the more southern regions, as well as the related mythical experience of the world, the infinity-experience, or the reality perceptions hosting unrealities. Travelling in this sense is an intermediate form of life: a movement towards other shapes. The direction and extent of this movement has always been defined by the 'straight line,' the main road, and later the straight line of the railway. The earlier horse-drawn vehicles were replaced by the train in 1825 (in Hungary in 1846). "Throughout the history of Central Eastern Europe, there have been trains running along, with or without any signs." (Bence 2008, 77) "As one who fell between the rails..."-says the frequently quoted line of the opening poem of the famous cycle (Dezső Kosztolányi: A szegény kisgyermek panaszai/ The Poor Little Boy's Grievances). (The well-known parody by Frigyes Karinthy: "As one who quietly stepped into it.") A manifestation of a similar regional experience is Apámmal utazunk a vonaton [Travelling with Father on the Train]:

Apámmal utazunk a vonaton.

Hideg, sugáros, éji nyugalom.

A szunnyadó csöndesség lomha, mély, de ébredez, hallucinál az éj. (...)

[I'm travelling with Father on the train.

Cold, beaming, nocturnal serenity.

Dormant silence, sluggish, deep, but waking, the night's hallucinating. (...)]

The dominant means of travel in Central Eastern Europe is the train. (Occasionally—in the oeuvres of Dezső Kosztolányi, Erzsébet Juhász, and István Szathmári-it is the tram but with a different meaning.) Among the emblematic literary examples (ranging from Sándor Petôfi's poem Vasúton [By Rail] written in 1847, through Orsolya Karafiáth's poem Nagypapa én és a keleti blokk [Granddad, Me and the Eastern Block], up to the story Veszteglö vonatok a sötétben [Stranded 
trains in the dark] and Bolond utazás [Mad trip]) and among the numerous 'relations' to 'trips by train' in Erzsébet Juhász's Határregény [Border novel] I would like to underline the metaphoric final image, the scene when on the empty Vienna Express Gézi, Margit’s “difficult-minded” son, unexpectedly starts running around in the corridor. According to the narrative comment: “ $\ldots$ at that moment, several centuries' paths of motion emerge along the corridor of this train speeding to Vienna, reproducing the multitude of past roads by incredible velocity, so that all this could be passed on to the decay of irrepressible oblivion." (Juhász 2001, 94)

It is at this point that the "Kosztolányi-Kiš összehasonlító szótár" [KosztolányiKiš Comparative Dictionary] by Éva Hózsa becomes very important:

Kosztolányi uses the introductory motif also known from Karinthy's parody as the expression of intermediacy. The rails open up a perspective; however, they can also get entangled: the tangle of rails is Kiš's metaphor. It is a hidden central kernel, which can be uncoiled, and related to Ahasuerus's wandering. The parallel ceases as soon as the wanderer starts travelling. The father relates both to the train schedule as well as to chaotic disappearance. In Kosztolányi's volume, the poem beginning with the line Apámmal utazunk a vonaton [I'm travelling with Father on the train] attempts to capture the impressions intruding the nocturnal peace, sounds and fragments of images. (Hózsa 2009a, 116)

In Hózsa's article, the opposition of 'parallelism,' i.e. 'travel according to the schedule,' and the wandering (chaos) is emphasized as a particularly significant motif to understand the Kosztolányi-Kiš discourse.

\section{Danilo Kišss transfers into Hungarian literature (in Vojvodina)}

In his interview bearing the title Élet, irodalom [Life, Literature], Danilo Kiš calls the father's (i.e. Eduard Sam's) Menetrend [Schedule] "a work of the Talmud" (Kiš 1994, 23) in the sense of explaining (existence). It was created by the symbolic necessity to bring order into the chaos of straight lines (roads, rail tracks) enmeshing the space (of existence) of Central Eastern Europe-an experiment to see through this space cut up by straight lines. A quote from the interview: "His work, Vasúti-, társasgépkocsi-, hajó- és repülógépjáratok Menetrendje [Schedule of trains, buses, ships and airplanes] became renown owing to my books." (Kiš 1994, 26) The same is mentioned in Kert, hamu [Garden, Ash] as "apocrypha, a sacral Bible," with a concrete reference to how to 'correct' and 'restore': in 
Schedule, the distances and separations between different places of the world become of 'the size of a human step.' (Kiš 2004, 38 [1965], [1967: in Hungarian])

As mentioned before, the history of the region is crisscrossed by trains with or without signs. The aim of Eduard Sam's order/schedule-creating act is to produce a state of transparency accomplished by marking these. Instead of the chaos caused by the lack of a schedule there arises the necessity to restore order:

After several unsuccessful businesses, my father got a position at the Railway Ministry where he made it all the way to the general inspectorate. Owing to this, the whole family travelled first-class for free until 1992, and the ticket collectors saluted my father like a general. (ibid.)

It is exactly this that seems to be the greatest paradox in the father's life: instead of the trains (roads) that he named and marked, he disappeared on an unscheduled train. Instead of the Schedule symbolizing order, absence is what interprets his existence in literature: "The scenes in which my father appears are a type of negatives: the prints of his Absence. Up to the present day, I still see him getting into a car, a carriage, boarding a train, or a tram. We are constantly expecting and seeing him off." (idem, 20)

\section{Departure and arrival}

In the presented space of existence, the experience of departure and arrival is a significant, notable moment in life thanks to which the notion of station also becomes a topic in art, moreover, in everyday life it gets an additional sacral meaning: 'the stations of human life.' Among its manifestations in literature, I would mention the scene when Pacsirta is leaving, and her parents are seeing her off to the station. Or the images from Árpád Nagy Abonyi's Budapest, Retour, which are created in Kornél Esti's mind when after a long time spent in emigration—now coming home for a funeral-his train pulls into the station. In the second short story on Kornél Esti, Mirror Tricks, the narrative comment summarizes the regional way of life: "The moment he spotted the worn railway station, melancholy came over him. He stopped in the deserted corridor of the station: he idly browsed through the ragged schedule, as if he was about to travel on.” (Nagy Abonyi 2003, 91) 


\section{How Eduard M. Kiš as a 'railway inspector' made it into literature}

Subsequent to literary transfers, transpasses and connections having been interpreted above, the way it is due and according to schedule, I wonder whether it is possible and necessary to answer the question posed. The model of family history, i.e. the encyclopedic work, which functions in Danilo Kiš’s oeuvre as a genre-creating mode, brings up moments analogous to the poetic of questioning the past historical narrative 'of present interest.' The essence is the possibility of crisis modeling, projections of personal destinies into the past; the interpretation of a personal biography in the past. Danilo Kiš cannot be envisaged otherwise but as a traveller, on the train.

\section{Works cited}

\section{Primary sources}

Dudás Károly. 1996. Esti Kornél utolsó hazalátogatása. [Kornél Esti’s Last Homecoming.] In Királytemetés [Burying the King], 164-166. Subotica: Életjel. Juhász Erzsébet. 1998. Után-utazás Esti Kornél fiumei gyorsán. [Travelling on Kornél Esti's Track on the Fiume Express Train.] In Úttalan utaim [My Untrodden Paths], 59-65. Novi Sad: Forum.

—. 2001. Határregény. [Border Novel.] Postscript by Kornélia Faragó, 91-101. Novi Sad: Forum.

Kiš, Danilo. 1986. A holtak enciklopédiája. [Encyclopedia of the Dead.] Translated by János Borbély. Novi Sad: Forum.

—. 1994. Kételyek kora. [The Age of Doubts.] Translated by Zita Balázs et al. Selection and postscript by János Bányai. Novi Sad - Bratislava: Forum Kalligram.

—. 1994. Lant és sebhelyek. [The Lute and the Scars.] Translated by Attila Balázs et al. Budapest: Pesti Szalon.

—. 2004. Bašta, pepeo. [Garden, Ashes.] Beograd: Biblioteka Novosti.

—. 2007. Gorki talog iskustva. [Interviews.] Priredila Mirjana Miočković. Beograd: Prosveta.

Kosztolányi Dezső. 2011. Esti Kornél. [Kornél Esti.] Eds. Júlia Tóth-Czifra and András Veres. Chapters on reception by András Veres. Bibliography by Éva Sárközi. Bratislava: Kalligram.

Lovas Ildikó. 2005. Kijárat az Adriára. James Bond Bácskában. [An Exit to the Adriatic: James Bond in Bačka.] Bratislava: Kalligram. 
Nagy Abonyi Árpád. 2003. Esti Kornél Bácskában. Esti Kornél hazatér. [Kornél Esti in Bačka. Kornél Esti Returns Home.] In Tükörcselek. [Mirror Tricks.], 8594. Zenta: zEtna.

—. 2008. Budapest, retour. Zenta: zEtna.

Szenteleky Kornél. 1993. Isola Bella. In Nyári délelótt. Egybegyüjtött novellák, regény. [Summer Morning. A Collection of Short Stories, a Novel.], 167-259. Postscript by Imre Bori, 271-280. Novi Sad: Forum.

\section{Secondary sources}

Babić, Sava. 2007. Kosztolányi Dezső és Danilo Kiš. [Dezső Kosztolányi and Danilo Kiš.] In Az emlékezés elevensége. Kosztolányi Dezsó Napok a szülóföldön. [The Vivacity of Remembrance. Dezsó Kosztolányi Days in the Homeland.], eds. Éva Hózsa, Zsuzsanna Arany and Gusztáv Kiss, 163-168. Subotica: Városi Könyvtár.

Bence Erika. 2007. A kert árnyéka. [The Shadow of the Garden.] Novi Sad: Forum.

—. 2008. Lentség és behatároltság. A vonat jelentésköre a közép-kelet-európai kultúrában [Down- and Boundedness. The Meaning of Trains in Central Eastern European Culture.] In $A X X$. század metaforái [Metaphors of the $20^{\text {th }}$ Century], 77-88. Zenta: zEtna.

Csányi Erzsébet. 1996. Az önfaló szöveg. Danilo Kiš Fövenyóra. [The SelfGobbling Text. Danilo Kiš Hourglass (1972).] In A regény öntudata. [The SelfConsciousness of the Novel], 61-88. Novi Sad: Forum - Uroboros.

—. 2010. Jeans mint stigma - szövet és szöveg. [Jeans as Stigma - Text and Texture.] In Farmernadrágos próza vajdasági tükörben. A vajdasági magyar jeans-próza természetrajza. [Prose wearing Jeans in the Mirror of Vojvodina. A Natural History of Hungarian Jeans-Prose in Vojvodina.], 11-20.Novi Sad: Faculty of Philosophy - Hungarian College for Higher Education in Vojvodina. Juhász Erzsébet. 1996. A tisztánlátás tébolya (Danilo Kiš Fövenyóra címú regénye mint a „mitteleurópai groteszk” egyik reprezentatív múve) [The Madness of Clairvoyance (Hourglass by Danilo Kiš as a Representative of the "Central European Grotesque”)]; Passió és emberhecc (Danilo Kiš Fövenyóra címú regényének egy fejezetéről) [Passion and Human Bantering (about a chapter from Danilo Kiš’s Hourglass)]; A cauchemar tükörkép-labirintusa (A „mitteleurópai groteszk" Danilo Kiš A holtak enciklopédiája címú kötetében) [The ImageLabyrinth of Cauchemar (the "Central European Grotesque" in Danilo Kišss volume Encyclopedia of the Dead]; Spirálörvény és burjánzás (A formatudat Mészöly Miklós és Danilo Kiš prózájában) [Vortex and Proliferation (Form Consciousness in the Prose of Miklós Mészöly and Danilo Kiš)] In Tükörképek labirintusa. Tanulmányok a közép-európai irodalmak köréból. [The Labyrinth of Images. Studies on Central European Literatures], 109-140. Novi Sad: Forum. 
Hózsa Éva. 2009. A novella Vajdaságban. [The Short Story in Vojvodina.] Novi Sad: Hungarian College for Higher Education in Vojvodina.

—. 2009a. A félelem álcái és arcai - A bennü(n)k beszélő világ (Danilo Kiš: Korai bánat és Kosztolányi Dezső: A szegény kisgyermek panaszai) [The Masks and Faces of Fear - The World Speaking within Us/Them (Danilo Kiš: Early Sorrows and Dezső Kosztolányi: The Complaints of the poor Little Child)] In Csáth-allé (és kitérók) [The Csáth-Alley (and other By-passes], 109-117. Subotica: Életjel. —. 2010. Nincs olyan Don Quijote, aki ne maradna egyedül. Kosztolányi Esti Kornéljának intertextuális mozgásai (Kosztolányi Dezső: Esti Kornél, Esti Kornél kalandjai és Esterházy Péter: Esti) [There is No Don Quijote Who Would Not Stay Alone. Intertextual Movements of Kosztolányi’s Kornél Esti (Dezső Kosztolányi: Kornél Esti, The Adventures of Kornél Esti, and Péter Esterházy: Esti]. In Alteregó. Alakmások - hamismások - heteronimák. [Alterego. Counterparts - Fakes - Heteronyms], ed. Erzsébet Csányi, 21-36. Novi Sad: Faculty of Philosophy - Hungarian College for Higher Education in Vojvodina. —. 2011. Esti Kornél ,átszállásai” a vajdasági magyar irodalomban (Korának vagy korunk hôse?) [Kornél Esti’s “Transfers” in the Hungarian Literature from Vojvodina]. In Melyik Kosztolányi(m)? Kapcsolatformálódások. [Which Kosztolányi (of Mine)? Connection Formations], 71-79. Subotica: Életjel.

Milosevits Péter. 1998. A szerb irodalom története. [The History of Serbian Literature.] Budapest: Nemzeti Tankönyvkiadó.

Orcsik Roland. 2004. Apokrifek. Esterházy Kiš archeológiájáról [Apocrypha. On the Kiš Archeology of Esterházy]. In Elmélet/Irodalom/Történet. [Theory/ Literature/History], eds. Miklós Sághy and Ákos Tóth, 203-224. Szeged: Tiszatáj Könyvek.

Rosić, Tatjana 2008. Mit o savremenoj biografiji - Danilo Kiš i figura pisca u srpskoj kulturi. Beograd: Institut za književnost is umetnost.

Rudaš Jutka. 2008. Esterházy versus Kiš. In jelHáló. Összehasonlító irodalomtudományi, nyelvészeti és médiaközi kutatások [signNet. Research in Comparative Literature, Linguistics and Inter-media], ed. Erzsébet Csányi,149-161. Novi Sad: Faculty of Philosophy - Hungarian College for Higher Education in Vojvodina. 